\title{
Specific Airway Conductance
}

National Cancer Institute

\section{Source}

National Cancer Institute. Specific Airway Conductance. NCI Thesaurus. Code C122186.

A measurement of the airway conductance relative to lung volume. 